\title{
Analisis Pembelajaran Daring di Sekolah Dasar pada Masa Pandemi Covid-19
}

\section{Peni Setyorini}

Universitas Sebelas Maret

peni.setyorini@student.uns.ac.id

\section{Article History}

received 30/4/2021

\begin{abstract}
The outbreak of Covid-19 in the world has caused restrictions in various fields, including the field of education, so the idea of implementing BDR education online has emerged. This policy was taken to break the chain of the spread of Covid-19. The purpose of this study is to analyze online learning in elementary schools during the Covid-19 pandemic. The results of the study indicate that learning activities during the Covid-19 pandemic are carried out online by utilizing the currently available digital platforms that are adapted to the abilities of teachers, students and parents as companions for learning at home. Online learning activities can run effectively in accordance with the creativity of teachers in delivering learning materials that are tailored to the ability of students to receive learning materials and good cooperation between teachers and parents is needed in the implementation of online learning.
\end{abstract}

Keywords: Covid-19, online learning, elementary school

\begin{abstract}
Abstrak
Mewabahnya Covid-19 di dunia menyebabkan adanya pembatasan di berbagai bidang tidak terkecuali bidang pendidikan sehingga muncul gagasan dilaksanakannya pendidikan secara BDR dengan cara daring. Kebijakan tersebut diambil guna memutus rantai penyebaran Covid19. Tujuan penelitian ini yakni menganalisis pembelajaran daring di Sekolah Dasar pada masa pandemi Covid-19. Hasil penelitian menunjukkan bahwa kegiatan pembelajaran selama pandemi Covid-19 dilaksanakan secara daring dengan memanfaatkan platform digital yang tersedia saat ini yang disesuaikan dengan kemampuan guru, peserta didik dan orang tua sebagai pendamping belajar di rumah. Kegiatan pembelajaran daring dapat berjalan efektif sesuai dengan kreatifitas guru dalam menyampaikan materi pembelajaran yang disesuaikan dengan kemampuan peserta didik dalam menerima materi pembelajaran serta, dibutuhkan kerjasama yang baik antara guru dan orang tua dalam pelaksanaan pembelajaran secara daring.
\end{abstract}

Kata kunci: Covid-19, pembelajaran daring, Sekolah Dasar 


\section{PENDAHULUAN}

Coronavirus deseases (COVID-19) teridentifikasi pertama kali menyebar di kota Wuhan, Cina pada Desember 2019. Virus yang menimbulkan gejala ringan hingga berat tersebut teridentifikasi pertama kali di Indonesia pada bulan Maret 2020. Virus yang menyebabkan gangguan pernapasan tersebut memiliki gejala yakni berupa batuk, bersin, demam dan sesak napas yang disebabkan oleh virus corona generasi baru (Sari, 2020: 82).

Seluruh masyarakat dari berbagai bidang merasakan dampak yang ditimbulkan dari menyebarnya virus tersebut. Semakin sering bertemu dengan orang lain maka peluang tertularnya virus tersebut juga semakin besar. Berbagai upaya dilakukan pemerintah untuk memutus rantai penularan Covid-19 yakni salah satunya dengan pembatasan kegiatan dalam berbagai bidang. Masyarakat diminta untuk menghindari kerumunan dan mengurangi mobilitas dengan tetap menjalankan aktivitas dari rumah. Hal tersebut berlaku untuk berbagai sektor, seperti halnya kegiatan belajar mengajar yang dilakukan oleh guru dan peserta didik dalam melaksanakan pembelajaran juga harus dilaksanakan dari rumah. Hal ini sesuai dengan Surat Edaran Kemendikbud No. 4 tahun 2020 yang berisikan tentang pedoman pelaksaan BDR. Sesuai dengan surat edaran tersebut, pelaksaan pembelajaran diselenggarakan secara daring yang fokus pada pengalaman hidup seperti halnya mengenai pandemi Covid-19. Guru memberikan umpan balik pada kegiatan yang dilakukan peserta didik secara kualitatif. Menurut Handarini (2020) mengatakan bahwa pembelajaran daring merupakan pembelajaran yang dilakukan secara jarak jauh. Adapun tujuan dari pembelajaran yang dilaksanakan secara daring yakni mempermudah komunikasi dan peyampaian pembelajaran antara guru dan peserta didik.

Pembelajaran yang dilaksanakan secara daring seperti halnya saat ini tentunya terdapat harapan di dalamnya. Menurut Anugraha (2020) harapan pembelajaran secara daring untuk masa sekarang ini yakni tercapainya tujuan pembelajaran yang telah ditetapkan. Adapun tujuan pada masa yang datang yaitu meningkatnya keterampilan peserta didik dan guru di era 4.0, pembelajaran daring dapat digunakan sebagai alternatif pembelajaran.

Pelaksanaan pembelajaran secara daring dilaksanakan di semua jenjang pendidikan tidak terkecuali Sekolah Dasar. Hal tersebut menuntut semua pihak yang terlibat untuk segera menyesuaikan diri. Tidak hanya guru dan peserta didik, orang tua sebagai pendamping belajar di rumah juga diharuskan menyesuaikan dengan keadaan demi terwujudnya pembelajaran daring yang maksimal seperti halnya pendapat Dewi (2020) mengatakan bahwa pembelajaran daring yang dilaksakan di Sekolah Dasar melibatkan peran orang tua. Pembelajaran secara daring dapat mempermudah peserta didik untuk belajar dimana pun dan kapan pun. Tidak seperti saat pembelajaran tatap muka yang mengharuskan peserta didik untuk belajar di sekolah dengan batas waktu tertentu, pada pembelajaran daring dapat dilaksanakan dimanapun dan kapanpun. Prawanti dan Sumarni (2020) mengatakan bahwa kendala yang dihadapi selama pembelajaran daring yakni kendala perangkat pendukung dan kurang pahamnya peserta didik dan orang tua pada platform yang tersedia menjadikan pembelajaran kurang efektif. Pembelajaran daring merupakan pola pembelajaran baru dimana guru berperan sebagai fasilitator dan peserta didik berperan aktif dalam pembelajaran (Anugrahana, 2020).

Pembelajaran daring yang dilakukan guru pada pelaksaan BDR saat ini tentunya membutuhkan berbagai aplikasi pendukung. Perkembangan teknologi saat ini memudahkan guru dalam melaksanakan pembelajaran daring dengan memanfaatkan platform yang tersedia seperti Google Classroom, Whatsapp, Email, Youtube, Zoom, Moodle, Google for Education, Quipper School, Rumah Belajar, dan Ruang Guru (Sulastri, Maula, \& Uswatun, 2020). Selain platform tersebut guru juga dapat menggunakan Google meet untuk melakukan video converence dan Google sites 
untuk membagikan bahan ajar. Kesiapan guru dan peserta didik dalam pembelajaran daring tidak menjadi penentu utama keberhasilan akan tetapi masih ada faktor lain seperti infrastuktur pendukung dalam pelaksanaan pembelajaran sebaimana pendapat Budhianto (2020) yang menyatakan bahwa faktor keberhasilan pembelajaran daring terdiri dari tiga faktor yakni infrastruktur pendukung, informasi yang disampaikan, dan pihak yang menggunakan dan yang mengatur.

Penelitian ini bertujuan untuk menganalisis pembelajaran daring di Sekolah Dasar pada masa pandemi Covid-19.

\section{HASIL DAN PEMBAHASAN}

Jenis virus baru yang mengakibatkan pandemi akhir-akhir ini merupakan varian baru yang patut kita waspadai sebagaimana pendapat Handayani dkk (2020) mengatakan bahwa penularan virus yang terjadi antar manusia tersebut disebabkan virus Corona baru yang menyebabkan infeksi saluran napas hingga ARDS. Virus yang dapat menyebar melalui percikan atau sering disebut droplet tersebut mengharuskan kita untuk menjaga jarak dengan orang lain. Kasus penularan virus yang semakin lama semakin banyak menimbulkan kekhawatiran bagi berbagai kalangan. Pencegahan penularan virus tersebut dapat dilakukan dengan mentaati protokol kesehatan sebagaimana anjuran dari pemerintah dengan cara memakai masker, cuci tangan dengan air mengalis dan sabun, jaga jarak, menghindari kerumunan, dan mengurangi mobilitas.

Kegiatan pembelajaran sebelum adaya pandemi dilaksanakan secara tatap muka tidak bisa dilaksanakan lagi. Kebijakan tersebut diambil oleh pemerintah untuk menjaga keselamatan bersama. Kegiatan pembelajaran tatap muka seperti halnya sebelum adanya pandemi memungkinkan adanya kerumunan. Hal tersebut menjadikan pemerintah melalui Kemendikbud memberikan alternatif pembelajaran selama pandemi Covid-19 dilaksakan secara daring dengan memanfaatkan perkembangan teknologi saat ini melalui berbagai platform yang tersedia. Pemanfaatan teknologi dengan benar dapat menjadikan penunjang pembelajaran daring seperti halnya dilakukan pada masa sekarang ini dengan memanfaatkan platform yang ada sehingga pembelajaran dapat berjalan efektif (Salsabila dkk, 2020). Kreatifitas dan memapuan guru dalam menyampaikan pembelajaran secara menarik sangat dibutuhkan. Guru dapat memanfaatkan aplikasi Whatsapp untuk mengkoordinasi peserta didik dalam pembelaran dan memantau proses pelaksanaan pembelajaran, dilanjutkan dengan kegiatan sinkronus dengan menggunakan Google meet atau Zoom untuk melakukan video converence. Kegiatan asinkronus dapat memanfaatkan Whatsapp, Google form, Google sites, Google Classroom, Whatsapp, Email, Youtube, Zoom, Moodle, Google for Education, Quipper School, Rumah Belajar, dan Ruang Guru. Penggunaan platform tersebut dalam pembelajaran tentunya disesuaikan dengan kemampuan dari sekolah, guru, peserta didik, orang tua, dan yang tidak kalah penting yakni ketersediaan jaringan serta perangkat pendukung. Menurut penelitian yang dilakukan oleh Widyaningsih (2020) dengan judul Penerapan Pembelajaran Online (Dalam Jaringan) di Sekolah Dasar yang menyatakan bahwa pembelajaran online dapat terlaksana dengan baik apabila adanya pelatihan, fasilitas mendukung, dan kekompakan antar guru dalam memberikan materi kepada peserta didik. Pembelajaran daring juga memberikan dampak positif bagi peserta didik karena peserta didik dapat mengakses berbagai sumber belajar belajar tentunya dengan bimbingan dan pengawasan orang tua.

Menurut Sulastri, Maula, \& Uswatun (2020) dalam penelitian yang berjudul Pemanfaatan Platform Digital Dlam pembelajaran Online Selama Masa Pandemi Covid-19 di Sekolah Dasar menyatakan bahwa platform digital yang efektif digunakan di SDN Tanjungsari yakni pemanfaatan fitur yang ada pada Whatsaap. Guru membuat grup whatsapp untuk mengkoordinasi kegiatan pembelajaran dengan diawali 
membagikan materi dan memberikan tugas. Peserta didik mengumpulkan tugas yang diberikan guru dengan memanfaatkan fitur yang ada pada aplikasi Whatsapp seperti mengirimkan video, foto, maupun pesan suara. Putra (2020) menyatakan bahwa pembelajaran yang dilaksanakan dengan Whatsapp group dapat berjalan dengan efektif karena dapat melaksanakan pembelajaran asinkronus maya, mandiri, dan kolaboratif tanpa harus bertemu secara langsung. Whatsapp digunakan dalam pembelajaran juga memperhatikan kemampuan dan kondisi dari guru, peserta didik dan orang tua.

Berdasarkan penelitian yang dilakukan oleh Pratiwi (2021) dengan judul Pelaksanaan Pembelajaran Daring dalam Masa Darurat Penyebaran Covid-19 di SD TI 030 Batu Belah Kelas VI menyatakan bahwa pembelajaran dari rumah yang dilaksanakan secara daring dapat dilaksanakan secara efektif. Sebagian besar peserta didik sudah memiliki gawai sendiri sehingga dapat dengan mudah mengakses pembelajaran yang disampaikan oleh guru. Pembelajaran yang dikemas melalui video juga menarik perhatian peserta didik, serta dengan memanfaatkan zoom guru dan peserta didik dapat berinteraksi walaupun secara tidak langsung.

Pembelajaran yang dilaksanakan secara daring seperti halnya pada masa sekarang ini tidak lepas dari dampak yang dirasakan oleh guru, peserta didik, dan orang tua. Menurut Sari, Tusyantari, \& Suswandari (2021) menyatakan bahwa dampak pembelaran daring bai guru yakni tidak semua guru mahir menggunakan teknologi, maka dari itu diperlukan adanya pelatihan penggunaan teknologi sehingga pembelajaran yang akan dilakukan dapat berjalan dengan baik. Dampak bagi peserta didik yakni kurangnya motivasi belajar yang sebelumnya dilaksanakan secara tatap muka dan sekarang harus belajar secara daring di rumah menyebabkan peserta didik merasa jenuh. Dampak bagi orang tua yakni bertambahnya pengeluaran orang tua karena digunakan untuk membeli kuota internet. Selain itu, orang tua juga harus membagi waktu antara membimbing anak belajar dan melakukan aktifitas sehari-hari. Semua hal tersebut dapat diminimalisir dengan semangat dan tekad yang kuat dari peserta didik, serta kerjasama yang baik antara guru dengan orang tua demi terwujudnya pembelajaran yang efektif di masa pandemi.

\section{SIMPULAN}

Berdasarkan paparan di atas dapat kita ketahui bahwa pembelajaran di Sekolah Dasar pada masa pandemi Covid-19 menggunakan pembelajaran secara daring dengan memanfaatkan platform digital yang disesuaikan dengan kemampuan dan kondisi peserta didik dan orang tua. Hal tersebut dilaksakan guna mengurangi kerumunan dan mobilitas sebagai cara yang ditempuh pemerintah untuk mengurangi penyebaran Covid-19. Guru memanfaatkan platform digital yang disesuaikan dengan kemampuan peserta didik dan orang tua dalam mengoperasikannya. Kegiatan pembelajaran daring dapat berjalan efektif sesuai dengan kreatifitas guru dalam menyampaikan materi pembelajaran yang disesuaikan dengan kemampuan peserta didik dalam menerima materi pembelajaran. Selain itu, hal yang tidak kalah penting yakni adanya kerjasama antara guru dengan orang tua dalam pembelajaran daring saat ini

\section{DAFTAR PUSTAKA}

Anugrahana, A.(2020). Hambatan, Solusi dan Harapan: Pembelajaran Daring Selama Masa Pandemi Covid-19 oleh Guru Sekolah Dasar. Jurnal Pendidikan dan Kebudayaan, 10 (3), 282-289. Diperoleh pada 19 Juli 2021, dari https://ejournal.uksw.edu/scholaria/article/view/4033. 
Budhianto, B. (2020). Analisis Perkembangan dan Faktor yang Mempengaruhi Keberhasilan Pembelajaran Daring (E-learning). Jurnal AgriWidya, 1 (1). Diperoleh pada 19 Juli 2021, dari http://repository.pertanian.go.id/bitstream/handle/123456789/10118/Analisis\%2 Operkembangan\%20dan\%20faktor\%20yang\%20mempengaruhi\%20keberhasila n\%20Pembelajaran\%20Daring\%20\%28ELearning\%29.pdf?sequence=2\&isAllo wed $=\mathrm{y}$.

Dewi, W. A. F. (2020). Dampak Covid-19 Terhadap Implementasi Pembelajaran Daring di Sekolah Dasar. Edukatif: Jurnal Ilmu Pendidikan, 2(1), 55-61. Diperoleh pada 19 Juli 2021, dari https://edukatif.org.

Handarini, O.I. (2020). Pembelajaran Daring sebagai Upaya Study From Home (SFH) Selama Pandemi Covid 19. Jurnal Pendidikan Administrasi Perkantoran (JPAP), 8 (3). Diperoleh pada 20 Juli 2021, dari https://journal.unesa.ac.id.

Handayani, D dkk. (2020). Penyakit Virus Corona 2019. J Respir Indo, 4 (2). Diperoleh pada 20 Juli 2021, dari https://jurnalrespirologi.org.

Pratiwi, A.S.(2021). Pelaksanaan Pembelajaran Daring dalam Masa Darurat Penyebaran Covid-19 di SD TI 030 Batu Belah Kelas VI, 5 (1). Diperoleh pada 20 Juli 2021, dari https://jptam.org/index.php/jptam/article/view/1022/915.

Prawanti, L.T dan Sumarni, W. (2020). Kendala Pembelajaran Daring Selama Pandemic Covid-19. Diperoleh pada 20 Juli 2021, dari https://proceeding.unnes.ac.id.

Putra, N.P.(2020).Solusi Pembelajaran Jarak Jauh Menggunakan Aplikasi Zoom dan Whatsapp Group di Era New Normal pada Warga Belajar Paket C di Pusat Kegiatan Belajar Masyarakat (PKBM) Bina Insani. JIPSINDO, 7 (2). Diperoleh pada 20 Juli 2021, dari https://journal.uny.ac.id/index.php/jipsindo/article/view/34939.

Salsabila, U.H., dkk. (2020). Pemanfaatan Teknologi Media Pembelajaran di Masa Pendemi Covid-19. Jurnal Pendidikan Dasar, 2 (2), 1-13. Diperoleh pada 20 Juli 2021, dari https://journal.uwks.ac.id.

Sari, M.K. (2020). Sosialisasi tentang Pencegahan Covid-19 di Kalangan Siswa Sekolah Dasar Di SD Minggiran 2 Kecamatan Papar Kabupaten Kediri. Jurnal Karya Abdi 4 (1). Diperoleh pada 19 Juli 2021, dari https://onlinejournal.unja.ac.id.

Sari, R.S., Tusyantari, N.B., \& Suswandari, M. (2021). Dampak Pembelajaran Daring Bagi Siswa Sekolah Dasar Selama Covid-19. Jurnal Ilmiah Kependidikan, 2 (1). Diperoleh pada 20 Juli 2021, dari https://ejournal.uniflor.ac.id/index.php/JPM/article/view/732

Sulastri, D., Maula, M.H., Uswatun, D.A.(2020). Pemanfaatan platform digital dalam Pembelajaran Online Selama Masa Pandemi Covid-19 di Sekolah Dasar. Jurnal Pendidikan Dasar. Diperoleh pada 20 Juli 2021, dari http://journal.unj.ac.id/unj/index.php/jpd/article/view/15891/9864 
Volume 9 Nomor 1 Tahun 2021

Widyaningsih, O.(2020). Penerapan Pembelajaran Online (Dalam Jaringan) di Sekolah Dasar. Jurnal Pendidikan Dasar 2020, 2 (2). Diperoleh pada 20 juli 2021, dari https://journal.uwks.ac.id. 